\title{
Tinjauan Karakteristik Pasien Dengan Kasus Positif COVID-19 di Puskesmas Kecamatan Matraman
}

\author{
Edi Kurnianto, Daniel Happy Putra, Puteri Fannya, Deasy Rosmala Dewi \\ Program Studi Rekam Medis dan Informasi Kesehatan, Fakultas Ilmu-Ilmu Kesehatan, \\ Universitas Esa Unggul, Jakarta, Indonesia \\ Jl. Arjuna Utara No. 9, Kebon Jeruk, Jakarta Barat, DKI Jakarta 11510 \\ Korepondensi E-mail: edikurnianto213@gmail.com
}

Submitted: 26 Agustus 2021, Revised: 2 Desember 2021, Accepted: 14 Desember 2021

\begin{abstract}
COVID-19 is an infectious disease caused by the acute respiratory syndrome coronavirus-2 (SARS-CoV-2). COVID-19 causes respiratory tract infections ranging from the common cold to serious illnesses such as Middle East Respiratory Syndrome (MERS) and Severe Acute Respiratory Syndrome (SARS). This study aim is to determine the characteristics of patients with positive cases of COVID-19 at the Matraman District Health Center. The characteristics data that collected as a variable are symptoms, age, gender and residence. This research uses a descriptive analysis research method with a quantitative approach. There are 495 data collected from epidemiological investigation forms. The sampling technique used in this study is simple random sampling with a checklist sheet collecting data method. Based on the results of data collection and analysis the majority of symptoms characteristic found in this research this positive case of COVID-19 researches at the Matraman District Health Center, the major characteristics of symptoms in COVID19 patients are patients with mild symptoms (59\%), 31-45 years old are the majority of patients (29\%), woman is the majority of gender characteristic (62\%), and most of the cases founded in the Pisangan Baru district. It is to be expected that health services can provided education to every community regarding health protocols especially for a group at risk to prevent and slowing down the rate of virus transmission in the Matraman area.
\end{abstract}

Keywords: COVID-19, characteristics of positive patients, epidemiology

\begin{abstract}
Abstrak
COVID-19 adalah adalah penyakit menular yang disebabkan oleh sindrom pernapasan akut coronavirus-2 (SARSCoV-2). COVID-19 menyebabkan penyakit infeksi saluran pernapasan dari flu biasa hingga penyakit yang serius seperti Middle East Respiratory Syndrome (MERS) dan Severe Acute Respiratory Syndrome (SARS). Penelitian ini bertujuan mengetahui karakteristik pasien dengan kasus positif COVID-19 di Puskesmas Kecamatan Matraman. Karakteristik yang dilihat pada penelitian ini adalah gejala, umur, jenis kelamin dan tempat tinggal. Metode penelitian ini dengan menggunakan analisis deskriptif pendekatan kuantitatif. Data yang digunakan adalah formulir penyelidikan epidemiologi sebanyak 495 formulir. Teknik pengambilan sampel yang digunakan pada penelitian adalah simpel random sampling dengan menggunakan lembar checklist. Berdasarkan hasil pengumpulan dan danalisis data didapatkan hasil yaitu karakteristik gejala pada pasien COVID-19 pada penelitian ini adalah gejala ringan (59\%), umur 31-45 tahun adalah mayoritas penderita covid 19 (29\%), jenis kelamin mayoritas adalah perempuan (62\%) dan mayoritas kasus terjadi di daerah Pisangan Baru (35\%). Pelayanan kesehatan diharapkan dapat memberikan edukasi kepada setiap masyarakat terkait tentang protokol kesehatan kepada kelompokkelompok yang berisiko untuk pencegahan dan memperlambat laju transmisi virus di wilayah Matraman.
\end{abstract}

Kata Kunci: Covid-19, karakteristik pasien positif, epidemiologi

\section{Pendahuluan}

Fasilitas Pelayanan Kesehatan adalah lembaga pelayanan kesehatan yang menyelenggarakan pelayanan kesehatan diantaranya promotif, preventif, kuratif, dan rehabilitatif yang dilakukan oleh pemerintah pusat, daerah, dan atau masyarakat (1). Jumlah puskesmas di Indonesia sampai dengan Desember 2017 adalah 9.825 unit dengan puskesmas rawat inap 3.454 unit dan puskesmas non rawat inap 6.371 unit (2). Lembaga-lembaga pelayanan kesehatan harus melaksanakan kegiatan promotif, preventif, kuratif dan rehabilitatif di fasyankes dan bukan hanya di puskesmas tetapi rumah sakit dan klinik harus melaksanakan kegiatan promotif, preventif, kuratif, dan rehabilitatif agar setiap masyarakat 
tetap berperilaku hidup sehat sehingga dapat mewujudkan, mempertahankan, dan memajukan kesehatan yang setinggi-tingginya untuk mencapai Indonesia yang sehat.

Penyakit menular dalam kamus bahasa inggris yaitu transmissible disease, communicable disease, atau contagious disease adalah penyakit dengan adanya agen penyebab yang mengakibatkan transmisi penularan penyakit dari orang atau hewan yang terinfeksi yang lebih rentan, secara langsung atau tidak langsung melalui perantara lingkungan hidup (3). Penyakit ini seperti Tuberculosis, HIV/AIDS, Influenza dan Covid-19. Virus corona termasuk penyakit menular yang menginfeksi saluran pernafasan atas sehingga COVID-19 di kategori sebagai kelompok penyakit yang menginfeksi pada manusia.

COVID-19 dalam bahasa inggris yaitu coronavirus disease 2019. Dalam bahasa latin corona artinya mahkota. Virus dapat dilihat dibawah mikroskop elektron dan berbentuk mirip korona seperti gerhana matahari dan mahkota ratu atau raja, virus ini dikenal sejak tahun 1930 yang terdapat pada hewan (4). Di tahun 2012, ada golongan virus corona yang mengakibatkan penyakit Middle East Respiratory Syndrome (MERS) di daerah Timur Tengah seperti Arab Saudi, Kuwait, Qatar, kasus di dunia melaporkan sebanyak 2.563 kasus konfirmasi MERS dengan kematian sebanyak 876 kasus di 27 negara. Pada bulan Maret tahun 2020 terdapat 51 kasus konfirmasi dengan 15 kematian sampai 31 Maret 2020 negara yang melaporkan kasus ini yaitu di daerah Timur Tengah. Di Indonesia terdapat kasus MERS sejak tahun 2013 sampai tahun 2020 yaitu sebanyak 576 suspek, dan kasus suspek MERS di Indonesia berdasarkan Provinsi yaitu di Sumatera Barat dengan 5 kasus, Gorontalo dengan 1 kasus, Kalimantan Timur dengan 1 kasus, Sulawesi Tenggara dengan 1 kasus, Banten dengan 5 kasus, Riau dengan 1 kasus, DKI Jakarta dengan 1 kasus (5).

Pada tahun 2020 World Health Organization (WHO) memberitahukan penemuan virus baru yang menyebabkan pneumonia dengan nama Severe Acute Respiratory Syndrome Coronavirus-2 (SARS-cov-2), virus COVID-19 telah bertransmisi dengan cepat ke berbagai Negara, berdasarkan data dari World Health Organization (WHO) secara global pada tanggal 02 November 2020 jam 9.37 a.m. Dengan kasus konfirmasi 46.166.182 kasus, meninggal 1.196.362 kasus. Berdasarkan Regional kasus COVID-19 di Negara America dengan kasus 20.616.596 kasus, Europe dengan kasus 11.062.715 kasus, South-East Asia dengan kasus 9.305.253 kasus, Eastern Mediterranean dengan kasus 3.118.628 kasus, Africa dengan kasus 1.324.258 kasus, Western Pacific dengan kasus 737.991 kasus (6). Sedangkan untuk kasus COVID-19 di Indonesia menurut Kementerian Kesehatan tanggal 02 November 2020 jam 12.00 WIB dengan kasus positif 415.402 kasus (+2.618), meninggal 14.044 kasus (+101 sekitar 3.4\%), kasus sembuh 345.566 (+3.624 sekitar 83.2\%) kasus (5). COVID-19 juga mempunyai kelompok-kelompok penyakit yang menginfeksi manusia.

Kelompok Penyakit COVID-19 terdiri dari empat subkelompok utama, yaitu alfa, beta, gama, dan delta. Virus yang paling sering menyebabkan penyakit pada manusia adalah tipe 229E, NL63, OC43, dan HKU1 (7). Karena COVID-19 adalah penyakit menular karena penyebaran/transmisi dari virus sangat cepat menginfeksi manusia sehingga bisa menginfeksi pada manusia dan mempunyai karakteristik gejala pada manusia yang terinfeksi Covid-19. Kelompok penyakit COVID-19 juga dikelompokan berdasarkan gejala, jenis kelamin, dan umur. Berdasarkan jenis kelamin, gejala, dan umur pasien COVID19 secara nasional tanggal 2 Desember 2020 dengan jenis kelamin pada pasien positif COVID-19 dengan laki-laki (50.4\%) dan perempuan (49,6\%). Pasien dirawat atau isolasi pada laki-laki (48,7\%) dan perempuan (51,3\%). Pasien sembuh pada laki-laki yaitu (50,5\%) dan perempuan (49,5\%). Pasien meninggal pada laki-laki (56,7\%) dan perempuan (43,3\%) (8).

Kelompok umur pasien positif COVID-19 yaitu umur 0-5 tahun sekitar 2,6\%, umur 6-18 tahun sekitar 8,8\%, umur 19-30 tahun sekitar 24,6\%, umur 31-45 tahun sekitar 30,4\%, umur 46-59 tahun sekitar 23,1\%, umur $>60$ tahun sekitar 10,4\%. Pasien di rawat/isolasi umur 0-5 tahun sekitar 3\%, umur 6-18 tahun sekitar 9,7\%, umur 19-30 tahun sekitar 24,4\%, umur 31-45 tahun sekitar 29,8\%, umur 46-59 tahun sekitar 23,1\%, umur >60 tahun sekitar 10,1\%. Pasien sembuh umur 0-5 tahun sekitar 2,6\%, umur 6-18 tahun sekitar 8,9\%, umur 19-30 tahun sekitar 25,4\%, umur 31-45 tahun sekitar 31\%, umur 46-59 tahun sekitar 22,6\%, umur $>60$ tahun sekitar 9,4\%. Pasien meninggal umur 0-5 tahun sekitar 0,9\%, umur 6-18 tahun sekitar 2,1\%, umur 19-30 tahun sekitar 6,9\%, umur 31-45 tahun sekitar 16,3\%, umur 46-59 tahun sekitar 36,6\%, umur $>60$ tahun sekitar 37,2\% (8).

Gejala-gejala positif COVID-19 meliputi batuk sekitar 68,4\%, demam sekitar 39,8\%, sesak nafas sekitar 30,5\%, lemas sekitar 28,1\%, pilek sekitar 27,4\%, sakit tenggorokan sekitar 24,3\%, sakit kepala sekitar 20,4\%, mual sekitar 15,7\%, nyeri otot sekitar 13,7\%, nyeri abdomen sekitar 6,8\%, diare sekitar 
6,2\%, menggigil sekitar 5,9\% (8). Karakteristik gejala pada pasien COVID-19 akan inkubasi sekitar 5-6 hari saat terpapar virus. Karakteristik pasien COVID-19 memiliki ciri-ciri gejala klinis yaitu demam, batuk, pilek, sesak nafas, sakit tenggorokan, nyeri otot, mual/muntah, nyeri abdomen, diare, malaise (lemah), sakit kepala, menggigil dan disertai setelah bepergian pada daerah dengan transmisi lokal atau kontak dengan kasus suspek/terkonfirmasi COVID-19(9). Gejala yang banyak dilaporkan oleh pasien COVID-19 serupa dengan gejala flu dan rata-rata waktu inkubasi dari virus Corona sekitar 5-6 hari. Gejala pada kasus yang berat dapat mengakibatkan gejala pneumonia, sindrome pernapasan akut, gagal ginjal serta meninggal.

Observasi awal penelitian ini dilakukan di Puskesmas Kecamatan Matraman yang berada di jalan Pisangan Baru Timur No.2A, RT.004 RW. 009, Kel. Pisangan Baru, Kec. Matraman, Kota Jakarta Timur. Puskesmas Kecamatan Matraman memiliki 13 Poliklinik, dan UP 24 jam, ruang Vk/Nifas/Observasi, ruang psikologi, ruang kesling, ruang konsultasi, ruang fisioterapi, laboratorium, farmasi, rekam medis, loket pendaftaran. Data laporan ini didapatkan dengan jumlah kasus positif COVID-19 pada bulan Agustus berjumlah 264 kasus dan pada bulan September kasus positif berjumlah 522 kasus, jadi dalam satu bulan ke depan terjadi peningkatan kasus sebesar 258 kasus.

Selama kasus Covid-19, Puskesmas Kecamatan Matraman bertugas sebagai pengawas dan pengontrol kasus Covid-19, semua kasus yang terindikasi positif lapor ke survailans untuk di data dan melakukan tracing kepada masyarakat yang kontak erat dengan pasien positif sehingga nanti akan didapatkan data, kemudian di tulis di formulir penyelidikan epidemiologi lalu dilakukan tes swab PCR kepada yang kontak erat tersebut sehingga menghasilkan data di formulir penyelidikan epidemiologi pasien positif dan didapatkan 87 formulir penyelidikan epidemiologi suspek Novel Coronavirus pasien positif bulan Agustus dan September. Pada hasil observasi di formulir penyelidikan epidemiologi ada gejala yang timbul adalah gejala ringan yaitu 33 pasien, gejala sedang yaitu 18 pasien dan gejala berat yaitu 0 pasien dan tanpa gejala yaitu 36 pasien.

Bahwa kasus COVID-19 dengan jumlah kasus positif dalam bulan Agustus dan September yaitu 786 kasus. Gambaran penduduk dan jumlah kasus positif COVID-19 di Puskesmas Kecamatan Matraman yaitu wilayah Kebon Manggis dengan jumlah penduduk 19.664 orang dengan jumlah kasus positif adalah 3 orang, Palmeriam dengan jumlah penduduk 29.498 orang dengan jumlah kasus positif adalah 13 orang, Pisangan Baru dengan jumlah penduduk 43.812 orang dengan jumlah kasus positif 39 orang, Kayu Manis dengan jumlah penduduk 42.269 orang dengan kasus positif adalah 9 orang, Utan Kayu Selatan dengan jumlah penduduk 33.910 orang dengan jumlah kasus positif adalah 9 orang, Utan Kayu Utara dengan jumlah penduduk 23.391 orang dengan jumlah kasus positif adalah 13 orang. Tujuan dari penelitian ini adalah untuk mengetahui karakteristik pasien dengan kasus positif COVID-19 di Puskesmas Kecamatan Matraman.

\section{Metode Penelitian}

Tempat pelaksanaan di Puskesmas Kecamatan Matraman yang berada di jalan Pisangan Baru Timur No.2A, RT.004 RW. 009, Kel. Pisangan Baru, Kec. Matraman, Kota Jakarta Timur, Daerah Khusus Ibukota Jakarta 13110. Penelitian dilaksanakan pada bulan Oktober 2020 - Januari 2021. Metode penelitian ini menggunakan penelitian kuantitatif. Populasi menggunakan formulir penyelidikan epidemiologi suspek Novel Coronavirus (2019-nCov) pada bulan Juni 2020 - Januari 2021 pasien positif dengan populasi 495 formulir. Sampel dalam penelitian ini adalah sebagian dari formulir penyelidikan epidemiologi pasien positif Covid-19. Teknik perhitungan sampel dilakukan dengan menggunakan rumus Slovin yang kemudian didapatkan hasil yaitu 221.

$$
n=\frac{\mathrm{N}}{1+\mathrm{N}(e)^{2}}
$$

Penelitian ini menggunakan teknik pengumpulan data yaitu observasi yang dilakukan dengan cara mengamati serta memantau formulir penyelidikan epidemiologi suspek novel coronavirus. Pengumpulan formulir penyelidikan epidemiologi pasien positif dilakukan dengan mengidentifikasi umur, jenis kelamin, gejala dan wilayah di formulir penyelidikan epidemiologi. Peneliti melakukan pengamatan terhadap formulir penyelidikan epidemiologi yang telah diisi oleh responden. Instrumen 
dalam pengumpulan data dengan menggunakan lembar checklist. Metode penelitian ini menggunakan teknik analisis deskriptif (univariat) pendekatan kuantitatif. Data formulir penyelidikan epidemiologi suspek novel coronavirus diolah dan di analisis dengan menggunakan statistik deskriptif.

\section{Hasil dan Pembahasan}

Berdasarkan Tabel 1 dapat diketahui bahwa dari 221 formulir penyelidikan epidemiologi mayoritas pasien COVID-19adalah gejala ringan, sedang, berat dan tanpa gejala, sebanyak 131 pasien $(59 \%)$ bergejala ringan yang tertinggi yaitu batuk dan yang terendah yaitu nyeri abdomen dan anosmia, bergejala sedang 19 pasien (9\%) yaitu sesak nafas dan tanpa gejala 71 pasien (32\%). Mayoritas pasien COVID-19 di Puskesmas Kecamatan Matraman adalah gejala ringan (59\%) yaitu batuk. Gejala ringan merupakan pasien dengan infeksi akut saluran napas atas tanpa komplikasi dengan ciri-ciri yaitu demam, fatigue, batuk (dengan atau tanpa sputum), anoreksia, malaise, nyeri tenggorokan serta sakit kepala (12).

Tabel 1.

Distribusi Frekuensi Formulir Berdasarkan gejala dan kriteria gejala pada pasien positif COVID-19 di Puskesmas Kecamatan Matraman.

\begin{tabular}{ccc}
\hline Gejala & Frekuensi & Presentase (\%) \\
\hline Ringan & 131 & $59 \%$ \\
Sedang & 19 & $9 \%$ \\
Berat & 0 & $0 \%$ \\
Tanpa Gejala & 71 & $32 \%$ \\
Total & 221 & $100 \%$ \\
\hline
\end{tabular}

Penelitian ini sesuai dengan penelitian lain dari (10) yang melakukan penelitian dengan konsep retrospective case series bahwa mayoritas gejala pada pasien COVID-19 adalah gejala ringan yaitu batuk. Karakteristik klinis pada penelitian tersebut adalah demam 48 pasien (77\%), batuk 50 pasien (81\%), ekspektorasi 35 pasien (56\%), sakit kepala 21 pasien (34\%), fatigue atau kelelahan 32 pasien (52\%), diare 3 pasien (8\%), dan bemoptisis 2 pasien (3\%), sesak napas 2 pasien (3\%) dan waktu rata-rata dari paparan penyakit adalah 4 hari.

Gejala sedang adalah pasien remaja atau dewasa dengan tanda klinis pneumonia dan tidak ada tanda pneumonia berat dengan ciri-ciri mayoritas gejala yang dialami yaitu sesak nafas, demam, batuk, napas cepat (11). Karakteristik gejala sedang pada pasien COVID-19 di Puskesmas Kecamatan Matraman adalah sesak nafas (9\%). Tanpa gejala adalah gejala yang tidak menimbul tanda gejala klinis (11).

Risiko penularan oleh orang-orang dengan sedikit atau tanpa gejala masih harus dihitung. Dalam satu kapal pesiar yang dikarantina, hingga 50\% kasus positif tidak menunjukkan gejala atau tidak menunjukkan gejala pada saat pengujian bahwa hingga $12 \%$ penularan terjadi sebelum kasus indeks mengembangkan gejala (12). Teridentifikasi ada 66 laporan kasus COVID-19 pasien tanpa gejala. Pada usia 0-9 tahun terdapat 13 pasien (19.1\%), usia 10-19 tahun terdapat 10 pasien (14,7\%), usia 20-29 tahun terdapat 11 pasien (16,2\%), usia 30-39 tahun terdapat 10 pasien (14,7\%), usia 40-49 tahun, usia 60-69 tahun, dan usia $>70$ tahun terdapat 5 pasien (7,4\%), usia 50-59 tahun terdapat 7 pasien (10,3\%)(13).

Pada Tabel 2 diketahui bahwa dari 221 formulir penyelidikan epidemiologi, untuk umur 0-5 tahun yaitu 14 pasien (6\%), umur 6-18 tahun yaitu 20 pasien (9\%), umur 19-30 tahun 43 pasien (19\%), umur 31-45 tahun 64 pasien (29\%), umur 46-59 tahun 52 pasien (24\%), umur $>60$ tahun 28 pasien (13\%). Penelitian ini sesuai dengan hasil penelitian lain dari Wu \& McGoogan bahwa berdasarkan mayoritas umur pasien yang terkena COVID-19 di negara China $(\mathrm{n}=44.672)$ adalah kelompok umur 30-79 tahun $(87 \%)(16)$, karena umur 31-45 tahun adalah usia produktif karena sebagian besar umur tersebut bekerja diluar rumah sehingga memiliki banyak interaksi sehingga resiko penularan COVID-19 jauh lebih tinggi. 
Tabel 2.

Distribusi Frekuensi Formulir Berdasarkan Umur pasien positif COVID-19 di Puskesmas Kecamatan Matraman.

\begin{tabular}{ccc}
\hline Usia (tahun) & Frekuensi & Presentase (\%) \\
\hline $0-5$ & 14 & $6 \%$ \\
$6-18$ & 20 & $9 \%$ \\
$19-30$ & 43 & $19 \%$ \\
$31-45$ & 64 & $29 \%$ \\
$46-59$ & 52 & $24 \%$ \\
$>60$ & 28 & $13 \%$ \\
Total & 221 & $100 \%$ \\
\hline
\end{tabular}

Berdasarkan Tabel 3 dapat diketahui bahwa dari 221 formulir penyelidikan epidemiologi, sebanyak 86 pasien (38\%) berjenis kelamin laki-laki, dan 136 pasien (62\%) berjenis kelamin perempuan. Hasil penelitian ini berbeda dengan Zarifin Arifin, dkk dimana pada umumnya COVID-19 memberikan dampak menular pada jenis kelamin laki-laki. Pada kasus COVID-19 berdasarkan gender di Provinsi Nusa Tenggara Barat dengan ( $\mathrm{n}=643$ ) jenis kelamin laki-laki dengan $62,5 \%$ dan perempuan dengan $37,5 \%$ (17). Hasil penelitian ini juga berdeda dengan penelitian dari Istituto Superiore karena pada umumnya COVID-19 memberikan dampak menular pada jenis kelamin laki-laki. Berdasarkan penelitian tersebut di Negara Italia laki-laki merupakan jenis kelamin mayoritas terpapar COVID-19 yaitu 14.720 $(59,7 \%)$ dibandingkan dengan jenis kelamin perempuan yaitu 9.941 (44,46\%) (18).

Tabel 3.

Distribusi Frekuensi Formulir Berdasarkan Jenis Kelamin pasien positif COVID-19 di Puskesmas Kecamatan Matraman.

\begin{tabular}{ccc}
\hline Jenis kelamin & Frekuensi & Presentase (\%) \\
\hline Laki-Laki & 85 & $38 \%$ \\
Perempuan & 136 & $62 \%$ \\
Total & 221 & $100 \%$ \\
\hline
\end{tabular}

Pada Puskesmas Kecamatan Matraman infeksi COVID-19 lebih banyak menyerang perempuan dibandingkan laki-laki. Berdasarkan dari analisis Bayu Jarot ada beberapa faktor yang menyebabkan perempuan terpapar COVID-19 yaitu: Perempuan lebih cenderung berjabat tangan $(87,2 \%)$ dibanding laki-laki $(75,3 \%)$, Perempuan lebih cenderung berkumpul atau tidak menjauhi keramaian $(81,2 \%)$ dibandingkan laki-laki $(71,1 \%)$, Perempuan lebih cenderung tidak menjaga jarak 1 meter $(77,5 \%)$ dibandingkan laki-laki (68,7\%), sehingga mengakibatkan potensi penularan virus yang tinggi (14).

Berdasarkan dari analisis Bayu Jarot terdapat beberapa faktor yang menyebabkan laki-laki terpapar COVID-19 yaitu: Laki-laki (88,5\%) tidak rutin mengenakan masker dibandingkan perempuan yaitu 94,8\%, Laki-laki (69,5\%) tidak rutin mencuci tangan dibandingkan perempuan (80,1\%), Laki-laki rutin memakai hand sanitizer $(70,5 \%)$ dibandingkan perempuan yang menggunakan cairan desinfektan $(83,6 \%)(14)$.

Laki-laki berisiko tinggi terpapar COVID-19 bahkan mengalami kematian. Secara biologis, tingkat imunitas laki-laki lebih rendah dibandingkan perempuan. Sedangkan, gaya hidup yang mengakibatkan laki-laki berisiko tinggi terpapar COVID-19 bahkan mengalami kematian adalah kebiasaan merokok. Laki-laki rentan mengalami COVID-19 dikarenakan lebih banyak berada di luar rumah, baik untuk bekerja maupun beraktifitas lainnya. Wanita memiliki tingkat pengetahuan dibandingkan laki-laki terutama epidemiologi dan faktor risiko COVID-19 (15). 
Berdasarkan Tabel 4 dapat diketahui bahwa dari 221 formulir penyelidikan epidemiologi, sebanyak 78 pasien (35\%) bertempat tinggal di daerah Pisangan Baru, dan Utan Kayu Selatan 50 pasien (23\%), Kayumanis 57 pasien (26\%), Palmeriam 22 pasien (10\%), masing - masing 7 pasien (3\%) bertempat tinggal di daerah Utan Kayu Utara dan Kebon Manggis.

Tabel 4.

Distribusi Frekuensi Formulir Berdasarkan Wilayah pasien positif COVID-19 di Puskesmas Kecamatan Matraman

\begin{tabular}{lcc}
\hline \multicolumn{1}{c}{ Wilayah } & Frekuensi & Presentase (\%) \\
\hline Utan Kayu Selatan & 50 & $23 \%$ \\
Pisangan Baru & 78 & $35 \%$ \\
Kayumanis & 57 & $26 \%$ \\
Palmeriam & 22 & $10 \%$ \\
Utan Kayu Utara & 7 & $3 \%$ \\
Kebon Manggis & 7 & $3 \%$ \\
\multicolumn{1}{c}{ Total } & 221 & $100 \%$ \\
\hline
\end{tabular}

Gambaran penduduk di Puskesmas Kecamatan Matraman yang ada di wilayah Kebon Manggis yaitu19.664 orang, Palmeriam yaitu 29.498 orang, Pisangan Baru yaitu 43.812 orang, Kayu Manis yaitu 42.269 orang, Utan Kayu Selatan yaitu 33.910 orang, Utan Kayu Utara yaitu 23.391 orang (16). Berdasarkan pengamatan peneliti terhadap perilaku penduduk di Puskesmas Kecamatan Matraman ini terjadi di wilayah Pisangan Baru. Hal ini terjadi secara jumlah penduduk karena Pisangan Baru merupakan wilayah yang sangat padat penduduknya, faktor kedua yang mendukung hal ini karena ketidakpatuhan masyarakat pada protokol kesehatan yang merupakan hal utama untuk melawan COVID-19 berdasarkan perintah dari Kementrian Kesehatan.

Daerah pinggiran kota memiliki wabah yang lebih rendah, tetapi juga memiliki fasilitas kesehatan yang tidak memadai untuk menangani wabah penyakit, terutama penyakit Covid-19 yang merupakan wabah baru. Ada beberapa faktor penyebaran virus ini seperti interaksi masyarakat, mobilitas, kepatuhan dalam penerapan protokol kesehatan. Kepadatan penduduk bukan faktor utama penyebaran Covid-19 di Sumatera Barat namun bisa menjadi katalisator (17).

\section{Kesimpulan}

Karakteristik pasien berdasarkan gejala dari total 221 formulir penyelidikan dapat disimpulkan bahwa $131(59 \%$ ) pasien mengalami gejala ringan, bergejala sedang yaitu 19 pasien (9\%) dan tanpa gejala yaitu 71 pasien (32\%). Karakteristik pasien berdasarkan umur dari total 221 formulir penyelidikan disimpulkan bahwa umur 0-5 tahun yaitu 14 pasien (6\%), umur 6-18 tahun yaitu 20 pasien (9\%), umur 19-30 tahun yaitu 43 pasien (19\%), umur 31-45 tahun yaitu 64 pasien (29\%), umur 46-59 tahun yaitu 52 pasien (24\%), umur >60 tahun yaitu 28 pasien (13\%). Karakteristik pasien berdasarkan jenis kelamin dari total 221 formulir penyelidikan disimpulkan bahwa 86 pasien laki-laki (38 dan 136 pasien (62\%) berjenis kelamin perempuan. Karakteristik pasien berdasarkan wilayah dari total 221 formulir penyelidikan disimpulkan bahwa wilayah yang terdapat penyebaran virus COVID-19 adalah wilayah Pisangan Baru dengan 78 pasien, Utan Kayu Selatan yaitu 50 pasien (23\%), Kayumanis yaitu 57 pasien (26\%), Palmeriam yaitu 22 pasien (10\%), masing-masing 7 pasien (3\%) bertempat tinggal di daerah Utan Kayu Utara dan Kebon Manggis.

\section{Daftar Pustaka}

1. Peraturan Pemerintah. Undang-Undang Republik Indonesia Nomor 36 Tabun 2009 Tentang Kesehatan. 2009.

2. Kementerian Kesehatan Republik Indonesia. Profil Kesehatan Indonesia 2018 [Internet]. Vol. 1227. 2018. 496 p. Available from: website: http://www.kemkes.go.id

3. Edberg SC. Global Infectious Diseases and Epidemiology Network (GIDEON): A World Wide Web-based 
program for diagnosis and informatics in infectious diseases. Clin Infect Dis. 2005;40(1):123-6.

4. Pane DN, Fikri M EL, Ritonga HM. Penyakit Virus Corona-19 (COVID-19). Vol. 53, Journal of Chemical Information and Modeling. 2018. 1689-1699 p.

5. Kementrian Kesehatan. Info Infeksi Emerging Kementerian Kesehatan RI [nternet]. Kemenkes. 2020. Available from: https://infeksiemerging.kemkes.go.id/

6. WHO. Brazil: WHO Coronavirus Disease (COVID-19) Dashboard | WHO Coronavirus Disease (COVID-19) Dashboard [Internet]. Who. 2020. Available from: https://covid19.who.int/\%0Ahttps:// covid19.who.int/region/wpro/country/cn\%0Ahttps:// covid19. who.int/?gclid=CjwKCAjwztL2BRATEiwAvnALcpJvfjoB2ZO9AW4cscOjOPpuNN isqVVlTkpdslGJOuXSFkrhbLCafxoCjB0QAvD_BwE\%0Ahttps://covid19.who.int/region/a $\mathrm{mro} /$ country/br

7. Tong TR. Severe Acute Respiratory Syndrome Coronavirus (SARS-CoV). Vol. 16, Perspectives in Medical Virology. 2006. p. 43-95.

8. Satgas Covid -19. Beranda Satgas Penanganan COVID-19 [Internet]. Satgas Covid -19. 2020. Available from: https://covid19.go.id/

9. Ramona F, Prakoeswa S. Dasamuka Covid-19. 2020;7:231-40.

10. Xu XW, Wu XX, Jiang XG, Xu KJ, Ying LJ, Ma CL, et al. Clinical findings in a group of patients infected with the 2019 novel coronavirus (SARS-Cov-2) outside of Wuban, China: Retrospective case series. BMJ. 2020;368(January):1-7.

11. Kementerian Kesehatan Republik Indonesia. Pedoman Pencegahan dan Pengendalian COVID-19. Buku pedoman Pencegah dan Pengendali COVID-19. 2017; (penyakit KLB):1-34.

12. Vetter P, Vu DL, L'Huillier AG, Schibler M, Kaiser L, Jacquerioz F. Clinical features of covid-19. BMJ [Internet]. 2020;369(April):1-2. Available from: http://dx.doi.org/doi:10.1136/bmj.m1470

13. Kronbichler A, Kresse D, Yoon S, Lee KH, Effenberger M, Shin J Il. Asymptomatic patients as a source of COVID-19 infections: A systematic review and meta-analysis. Int J Infect Dis. 2020;98:180-6.

14. Bayu Jarot D. Mengapa Pria Lebih Rentan Terpapar Covid-19 - Analisis Data Katadata [Internet]. katadata. $2020 . \quad$ Available from: https://katadata.co.id/muhammadridhoi/analisisdata/5f7c0fe0dd610/mengapa-pria-lebihrentan-terpapar-covid-19

15. Illah Nur MN. Analisis Pengaruh Komorbid, Usia, Dan Jenis Kelamin Terbadap Meningkatnya Angka Kematian Pada Masa Pandemi COVID-19. 2021;1:1228-33.

16. Statistik BP. Dalam Angka Dalam Angka [Internet]. BPS Kota Jakarta Timur. 2020. 1-68 p. available from:

https://jaktimkota.bps.go.id/publication/download.html?nrbvfeve=mwjkowexzgm4nwe2ngi0 ntk1 mjewyjzj\&xzmn=ahr0chm6ly9qywt0aw1 rb3rhlmjwcy5nby5pzc9wdwjsawnhdglvbi8ymdiwl za5lzi4lzfizdlhmwrjodvhnjrindu5ntixmgi2yy9rzwnhbwf0yw4tbwf0cmftyw4tzgfsyw0tyw5na2et mjaymc5od

17. Ulva F, Yuliza WT. Hubungan Kepadatan Penduduk dengan Sebaran Kasus Covid-19 di Sumatera Barat Relationship Of Population Density and The Distribution of Covid-19 Cases in West Sumatera. 2020;5(2):263-7. 